\title{
PEMODELAN PINDAH PANAS PADA PROSES STERILISASI GUDEG KALENG
}

\author{
Asep Nurhikmat ${ }^{*}$, Bandul Suratmo, Nursigit Bintoro, dan Suharwadji \\ Jurusan Teknik Pertanian, Fakultas Teknologi Pertanian, Universitas Gadjah Mada, \\ J1. Flora, Bulaksumur, Yogyakarta 55281, Indonesia \\ ${ }^{*}$ Penulis Korespondensi: asep.nurhikmat@yahoo.com
}

\begin{abstract}
HEAT TRANSFER MODELLING ON STERILIZATION PROCESS CANNED GUDEG. The sterilization process on canning conducted to destroy spoilage bacteria. Gudeg temperature rise slowly during the sterilization process. Modeling of heat transfer in the process of canned gudeg sterilization has been done. The model was developed to predict the rise in gudeg temperatures were

$\mathrm{T}_{\mathrm{i}, \mathrm{j}}^{(\mathrm{t}+\Delta \mathrm{t})}=\mathrm{T}_{\mathrm{i}, \mathrm{j}}{ }^{\mathrm{t})}+\frac{\alpha \Delta \mathrm{t}}{\Delta \mathrm{r}^{2}}\left(\mathrm{~T}_{\mathrm{i}-1, \mathrm{j}}-2 \mathrm{~T}_{\mathrm{i}, \mathrm{j}}+\mathrm{T}_{\mathrm{i}+1, \mathrm{j}}\right)^{(\mathrm{t})}+\frac{\alpha \Delta \mathrm{t}}{2 \mathrm{r} \Delta \mathrm{r}^{2}}\left(\mathrm{~T}_{\mathrm{i}-1, \mathrm{j}}-\mathrm{T}_{\mathrm{i}+1, \mathrm{j}}\right)^{(\mathrm{t})}+\frac{\alpha \Delta \mathrm{t}}{\Delta \mathrm{z}^{2}}\left(\mathrm{~T}_{\mathrm{i}, \mathrm{j}-1}-2 \mathrm{~T}_{\mathrm{i}, \mathrm{j}}+\mathrm{T}_{\mathrm{i}, \mathrm{j}+1}\right)^{(\mathrm{t})}$. The purpose of the research is to determine the heat transfer phenomena in the process of sterilization canned gudeg using computer simulations and determine the effect of various treatments on the value of sterility and gudeg texture. The study was conducted the sterilization temperatures of 111, 121 and $131^{\circ} \mathrm{C}$ and the sterilization times 10, 20 and 30 minutes. Analysis of sterility values ( $F$ value) of products and gudeg texture was conducted to determine the most optimum treatment variations. Simulation models performed using MATLAB R2010a version. The research resulted fittings of data between predictions and observations were valid with a regression coefficient of 0.987 to 0.997 . The simulation results indicate that the material temperature showed that the higher the temperature and the longer the sterilization process had been done, it might caused darker colors of product. The most optimum treatment obtained at sterilization temperature of $121^{\circ} \mathrm{C}$ for 20 minutes with sterility value of 4.32 minutes and texture value of $11.23 \mathrm{~N} / \mathrm{mm}^{2}$.
\end{abstract}

Keywords: canned gudeg; modeling of heat transfer; sterilization process

\begin{abstract}
Abstrak
Proses sterilisasi pada pengalengan gudeg dilakukan untuk menghancurkan bakteri pembusuk. Kenaikan suhu gudeg selama sterilisasi terjadi secara perlahan-lahan. Pemodelan pindah panas pada proses sterilisasi gudeg kaleng telah dilakukan. Model yang dikembangkan untuk memprediksi kenaikan suhu gudeg

adalah

$\mathrm{T}_{\mathrm{i}, \mathrm{j}}^{(\mathrm{t}+\Delta \mathrm{t})}=\mathrm{T}_{\mathrm{i}, \mathrm{j}}^{(\mathrm{t})}+\frac{\alpha \Delta \mathrm{t}}{\Delta \mathrm{r}^{2}}\left(\mathrm{~T}_{\mathrm{i}-1, \mathrm{j}}-2 \mathrm{~T}_{\mathrm{i}, \mathrm{j}}+\mathrm{T}_{\mathrm{i}+1, \mathrm{j}}\right)^{(\mathrm{t})}+\frac{\alpha \Delta \mathrm{t}}{2 \mathrm{r} \Delta \mathrm{r}^{2}}\left(\mathrm{~T}_{\mathrm{i}-1, \mathrm{j}}-\mathrm{T}_{\mathrm{i}+1, \mathrm{j}}\right)^{(\mathrm{t})}+\frac{\alpha \Delta \mathrm{t}}{\Delta \mathrm{z}^{2}}\left(\mathrm{~T}_{\mathrm{i}, \mathrm{j}-1}-2 \mathrm{~T}_{\mathrm{i}, \mathrm{j}}+\mathrm{T}_{\mathrm{i}, \mathrm{j}+1}\right)^{(\mathrm{t})} \cdot$ Tujuan penelitian adalah untuk mengetahui fenomena pindah panas pada proses sterilisasi gudeg kaleng dengan menggunakan simulasi komputer dan mengetahui pengaruh berbagai variasi perlakuan terhadap nilai sterilitas dan tekstur gudeg. Penelitian dilakukan pada suhu sterilisasi 111, 121 dan $131^{\circ} \mathrm{C}$ dengan lama sterilisasi 10, 20 dan 30 menit. Analisis nilai sterilitas (nilai F) produk dan tekstur gudeg dilakukan untuk mengetahui variasi perlakuan yang paling optimum. Simulasi model dilakukan dengan menggunakan MATLAB versi R2010a. Penelitian menghasilkan fitting data antara prediksi dan observasi cukup valid dengan koefisien regresi antara 0,987 sampai 0,997. Hasil simulasi profil kenaikan suhu bahan mengindikasikan bahwa semakin tinggi suhu dan semakin lama proses sterilisasi berlangsung warna produk semakin gelap. Perlakuan paling optimum didapatkan pada suhu sterilisasi $121^{\circ} \mathrm{C}$ selama 20 menit dengan nilai sterilitas sebesar 4,32 menit dan nilai tekstur sebesar 11,23 $\mathrm{N} / \mathrm{mm}^{2}$
\end{abstract}

Kata kunci : gudeg kaleng; pemodelan pindah panas; proses sterilisasi 
How to Cite This Article: Nurhikmat, A., Suratmo, B., Bintoro, N., dan Suharwadji, (2014), Pemodelan Pindah Panas pada Proses Sterilisasi Gudeg Kaleng, Reaktor, 15(1), 64-72, http://dx.doi.org/ 10.14710/reaktor.15.1.64-72

\section{PENDAHULUAN}

Pengalengan makanan adalah suatu cara pengawetan bahan pangan yang dikemas dengan sangat rapat, sehingga tidak dapat ditembus oleh udara, air dan mikroba (hermetis). Makanan kaleng akan tetap terjaga dari perubahan kadar air, perubahan cita rasa dan proses oksidasi yang menyebabkan kebusukan. Teknologi ini dapat diterapkan pada hampir semua jenis makanan seperti sayuran, buah, daging, ikan, unggas, susu, telur, dan berbagai jenis minuman (Larousse dan Brown, 1997).

Pengalengan bukan merupakan teknologi baru tetapi masih banyak hal yang belum dikuasai terutama pada tahapan prosesnya. Salah satunya adalah optimasi sterilisasi untuk mematikan mikroba tetapi tetap menjaga kualitas produk yang dihasilkan (Awuah dkk., 2007). Sterilisasi merupakan cara pengawetan paling efektif namun mempunyai pengaruh merugikan terhadap zat gizi dan kualitas makanan (Lund, 2003).

Sterilisasi adalah operasi yang paling penting dalam proses pengalengan makanan. Proses ini bertujuan untuk menghancurkan mikroba pembusuk dan patogen, membuat produk menjadi cukup masak, tekstur dan cita rasa sesuai dengan yang diinginkan. Oleh karena itu proses pemanasan ini harus dilakukan pada suhu yang cukup tinggi untuk menghancurkan mikroba, tetapi tidak boleh terlalu tinggi sehingga membuat produk menjadi terlalu masak (Chinesta dkk., 2002; Kiziltas dkk., 2010). Jumlah panas yang diperlukan untuk sterilisasi yang memadai tergantung pada beberapa faktor antara lain ukuran kaleng, jenis bahan, $\mathrm{pH}$, jenis mikroba, suhu awal bahan dan sumber panas (Kiziltas dkk., 2010).

Selama proses sterilisasi berlangsung, suhu produk tidak akan segera mencapai suhu sesuai dengan yang dikehendaki, tetapi rambatan panas terjadi secara perlahan-lahan. Kecepatan perambatan panas ke dalam makanan dapat diketahui dengan heat penetration test dengan menempatkan termokopel pada bagian terdingin (cold spot) (Stoforos, 1995).

Beberapa penelitian yang telah dilakukan oleh Marra dan Romano (2003) adalah mengobservasi lokasi titik terdingin dalam dimensi kaleng berbeda yang diestimasi oleh kenaikan suhu bahan dan menentukan nilai sterilitasnya. Sementara Dewitt dan Incropera (2001), memfokuskan pada kecepatan perubahan suhu, profil konsentrasi, lokasi dan perubahan zona titik terdingin dan efek modifikasi geometri.

Model perpindahan panas yang terjadi pada sterilisasi makanan kaleng akan mengikuti koordinat silinder, dengan persamaan umumnya sebagai berikut (Ibarz dan Canovas, 2002):

$$
\frac{1}{\mathrm{r}} \frac{\partial}{\partial \mathrm{r}}\left(\mathrm{r} \frac{\partial \mathrm{T}}{\partial \mathrm{r}}\right)+\frac{1}{\mathrm{r}^{2}} \frac{\partial^{2} \mathrm{~T}}{\partial \theta^{2}}+\frac{\partial^{2} \mathrm{~T}}{\partial \mathrm{z}^{2}}+\frac{\mathrm{q}^{\prime \prime}}{\mathrm{k}}=\frac{1}{\alpha} \frac{\partial \mathrm{T}}{\partial \mathrm{t}}
$$

Menurut Dewitt dan Incropera (2001), perpindahan panas pada makanan kaleng tersebar merata di setiap sudut $\theta$ sehingga $\partial^{2} \mathrm{~T} / \partial \theta^{2}=0$ dan tidak terjadi panas yang dibangkitkan pada bahan pangan maka $\mathrm{q}^{\prime \prime \prime}=0$, maka persamaan (1) menjadi :

$$
\frac{1}{\alpha} \frac{\partial \mathrm{T}}{\partial \mathrm{t}}=\frac{\partial^{2} \mathrm{~T}}{\partial \mathrm{r}^{2}}+\frac{1}{\mathrm{r}} \frac{\partial \mathrm{T}}{\partial \mathrm{r}}+\frac{\partial^{2} \mathrm{~T}}{\partial \mathrm{z}^{2}}
$$

Untuk menyelesaikan persamaan (2) digunakan konsep penyelesaian numerik dengan metode beda hingga yaitu mengubah sistem persamaan diferensial parsial ke sistem persamaan aljabar biasa dengan mendiskritkan ruang domainnya. Suhu dijabarkan sebagai fungsi posisi $\mathrm{r}$ dan $\mathrm{h}$ atau $\mathrm{z}$ serta waktu yang didiskritkan sebagai fungsi t.

Dengan pendekatan beda hingga (finite difference approximation) pada diskritisasi potongan kemasan akan didapatkan skema perhitungan sesuai dengan persamaan (3) untuk tiap-tiap titik seperti terlihat pada Gambar 1.

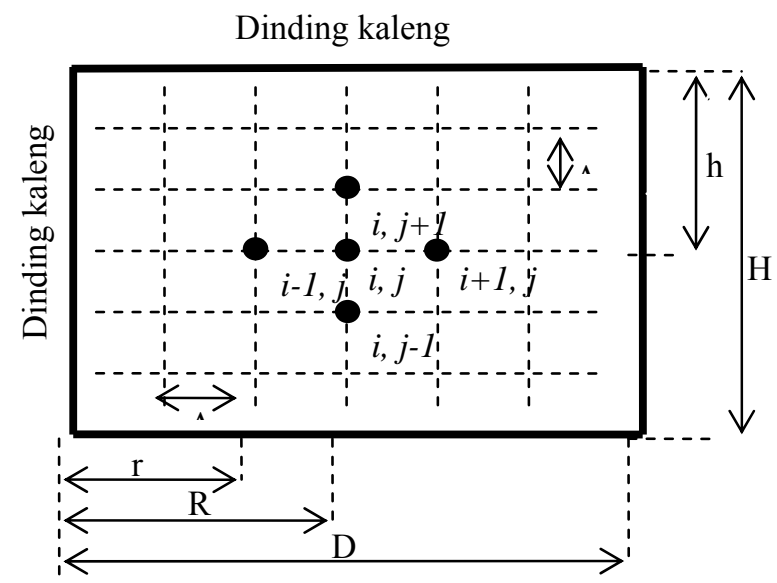

Gambar 1. Skema titik-titik perhitungan dengan metode beda hingga pada kaleng (Larousse dan Brown, 1997)

Dimana $: \mathrm{r}=\mathrm{i} \Delta \mathrm{r}$

$\mathrm{h}=\mathrm{j} \Delta \mathrm{h}$;

$\mathrm{t}=\mathrm{k} \Delta \mathrm{t}$;

$\mathrm{i}=1,2,3, \ldots \ldots . . \mathrm{n}_{\mathrm{r}}$

$\mathrm{j}=1,2,3, \ldots \ldots . . \mathrm{n}_{\mathrm{h}}$;

$\mathrm{k}=1,2,3, \ldots \ldots \ldots \mathrm{n}_{\mathrm{t}}$

$$
\frac{\mathrm{T}_{\mathrm{i}, \mathrm{j}}^{(\mathrm{t}+\Delta \mathrm{t})}-\mathrm{T}_{\mathrm{i}, \mathrm{j}}{ }^{(\mathrm{t})}}{\Delta \mathrm{t}}=\alpha\left(\frac{\mathrm{T}_{\mathrm{i}-1, \mathrm{j}}-2 \mathrm{~T}_{\mathrm{i}, \mathrm{j}}+\mathrm{T}_{\mathrm{i}+1, \mathrm{j}}{ }^{(\mathrm{t})}}{(\Delta \mathrm{r})^{2}}\right)+\frac{\alpha}{\mathrm{r}}\left(\frac{\mathrm{T}_{\mathrm{i}-1, \mathrm{j}}-\mathrm{T}_{\mathrm{i}+1, \mathrm{j}}}{2 \Delta \mathrm{r}^{2}}\right)+\alpha\left(\frac{\mathrm{T}_{\mathrm{i}, \mathrm{j}-1}-2 \mathrm{~T}_{\mathrm{i}, \mathrm{j}}+\mathrm{T}_{\mathrm{i}, \mathrm{j}+1}}{(\Delta \mathrm{z})^{2}}\right)
$$




$$
\mathrm{T}_{\mathrm{i}, \mathrm{j}}^{(\mathrm{t}+\Delta \mathrm{t})}=\mathrm{T}_{\mathrm{i}, \mathrm{j}}{ }^{(\mathrm{t})}+\frac{\alpha \Delta \mathrm{t}}{\Delta \mathrm{r}^{2}}\left(\mathrm{~T}_{\mathrm{i}-1, \mathrm{j}}-2 \mathrm{~T}_{\mathrm{i}, \mathrm{j}}+\mathrm{T}_{\mathrm{i}+1, \mathrm{j}}\right)^{(\mathrm{t})}+\frac{\alpha \Delta \mathrm{t}}{2 \mathrm{r} \Delta \mathrm{r}^{2}}\left(\mathrm{~T}_{\mathrm{i}-1, \mathrm{j}}-\mathrm{T}_{\mathrm{i}+1, \mathrm{j}}\right)^{(\mathrm{t})}+\frac{\alpha \Delta \mathrm{t}}{\Delta \mathrm{z}^{2}}\left(\mathrm{~T}_{\mathrm{i}, \mathrm{j}-1}-2 \mathrm{~T}_{\mathrm{i}, \mathrm{j}}+\mathrm{T}_{\mathrm{i}, \mathrm{j}+1}\right)^{(\mathrm{t})}
$$

Persamaan 3 adalah persamaan umum pindah panas konduksi bentuk silinder dalam persamaan aljabar biasa, sedangkan untuk mencari suhu (T) pada posisi $(i, j)$ pada waktu $(t+\Delta t)$ dapat dihitung dengan persamaan (4). Persamaan tersebut merupakan penyelesaian dari persamaan umum pindah panas secara konduksi yang digunakan pada titik-titik di bagian dalam silinder. Indeks i pada menunjukkan titik perhitungan hasil diskritisasi arah radial (r) sedangkan indeks $\mathrm{j}$ menunjukkan titik perhitungan hasil diskritisasi arah aksial (z).

Untuk menghitung persamaan 4 secara bersamaan dapat digunakan simulasi komputer. Kannan dan Sandaka (2008) menyajikan aliran panas transien dan pola suhu prediksi dari simulasi numerik pada perpindahan panas konveksi alami yang terjadi pada pemanasan kaleng yang tidak seragam. Dalam banyak publikasi simulasi numerik perpindahan panas pada proses sterilisasi makanan kaleng dapat mengidentifikasi zona perambatan panas paling lambat (Goncalves dkk., 2005; Kiziltas dkk., 2010). Untuk melakukan simulasi diperlukan kondisi awal dan kondisi batas dari sistem yang akan dipelajari.

\section{Kondisi Awal}

Suhu ( $\mathrm{T}$ ) pada saat $\mathrm{t}=0$ di seluruh titik perhitungan arah radial (i) dan arah aksial (j) berlaku :

$$
\mathrm{T}_{\mathrm{i}, \mathrm{j}}^{0}=\mathrm{T}_{\mathrm{awal}} \mathrm{i}=-\mathrm{n}_{\mathrm{r}}, \mathrm{n}_{\mathrm{r}} \quad \mathrm{j}=-\mathrm{n}_{\mathrm{z}}, \mathrm{n}_{\mathrm{z}}
$$

\section{Kondisi Batas}

1. Pada posisi $\mathrm{r}=0$ (sepanjang sumbu vertikal, kecuali di pusat)

$$
T_{0, j}^{t+\Delta t}=T_{j}{ }^{(t)}+\frac{4 \alpha \Delta t}{\Delta r^{2}}\left(T_{1, j}-T_{j}\right)^{(t)}+\frac{\alpha \Delta t}{\Delta z^{2}}\left(T_{j-1}-2 T_{j}+T_{j+1}\right)^{(t)}
$$

2. Pada $z=0$ (sepanjang sumbu horizontal kecuali di pusat)

$$
\mathrm{T}_{\mathrm{i}, 0}^{\mathrm{t}+\Delta \mathrm{t}}=\mathrm{T}_{\mathrm{i}}^{(\mathrm{t})}+\frac{2 \alpha \Delta \mathrm{t}}{\Delta \mathrm{r}^{2}}\left(\mathrm{~T}_{\mathrm{i}, 1}-\mathrm{T}_{\mathrm{i}}\right)^{(\mathrm{t})}
$$

3. Pada posisi $\mathrm{r}=0$ dan $\mathrm{z}=0$ (pada bagian pusat)

$$
\mathrm{T}_{0,0}^{\mathrm{t}+\Delta \mathrm{t}}=\mathrm{T}^{(\mathrm{t})}+\frac{4 \alpha \Delta \mathrm{t}}{\Delta \mathrm{r}^{2}}\left(\mathrm{~T}_{1}-\mathrm{T}\right)^{(\mathrm{t})}
$$

4. Pada posisi $\mathrm{r}=\mathrm{R}$ saat $\mathrm{t}>0$

$$
\left.\mathrm{T}\right|_{\mathrm{r}=\mathrm{R}, \mathrm{z}, \mathrm{t}>0}=\mathrm{T}_{\text {uap }}
$$

5. Pada posisi $\mathrm{z}=\mathrm{H}$ saat $\mathrm{t}>0$

$$
\left.\mathrm{T}\right|_{\mathrm{z}=\mathrm{H}, \mathrm{r}, \mathrm{t}>0}=\mathrm{T}_{\mathrm{uap}}
$$

Kestabilan model matematis yang dikembangkan merupakan faktor yang perlu diperhatikan. Kriteria kestabilan ditentukan oleh nilai koefisien pada titik-titik atau posisi yang berbeda (Chinesta dkk., 2002).

Gorunescu (2011) berpendapat bahwa model yang dikembangkan harus cocok dengan kasus yang dihadapi dan menentukan apakah model yang telah dibangun dapat menjawab permasalahan yang dihadapi. Menurut Widodo dkk. (2013) proses tersebut biasanya dikenal sebagai data mining. Data mining dilakukan dengan teknologi dan data base administrator yang mengikuti perkembangan yang ada. Salah satu jenis alogartima yang saat ini banyak dikembangkan adalah program komputer.

Menurut Gorunescu (2011), beberapa tahapan data mining yang harus dilakukan adalah eksplorasi data, pembuatan model dan validasi serta penerapan model. Metode yang dapat dipakai dengan membangun model berdasarkan data yang diamati antara lain dengan metode prediksi, yaitu memprediksi nilai yang akan datang berdasarkan data-data yang telah ada dengan regresi (Widodo dkk., 2013).

Tujuan penelitian adalah 1) untuk mengetahui fenomena pindah panas pada proses sterilisasi gudeg kaleng dengan menggunakan simulasi komputer; 2) untuk mengetahui pengaruh proses sterilisasi terhadap nilai sterilitas dan tekstur gudeg kaleng; dan 3) Untuk mengetahui perlakuan sterilisasi gudeg kaleng yang optimum.

\section{METODE PENELITIAN}

Sampel gudeg yang digunakan adalah gudeg kaleng $\mathrm{Bu}$ Tjitro dengan komposisi Gudeg 48,63 \pm $1,37 \%$; telor $22,77 \pm 1,23 \%$; krecek $13,92 \pm 1,42 \%$; kacang tolo $7,53 \pm 0,53 \%$ dan daging ayam 7,79 \pm $0,65 \%$, dimasukkan ke dalam kaleng jenis two pieces can ukuran diameter 74,92 $\mathrm{mm}$ dan tinggi 58,22 $\mathrm{mm}$ (300x205). Spesifikasi enamel (lacquer) badan kaleng bagian luar adalah clear lacquer (transparan) dan bagian dalam kaleng adalah aluminize lacquer (aluminium); tutup kaleng model easy open end (E.O.E).

Alat yang digunakan dalam penelitian antara lain: Retot Merk TOMMY SS-325 dengan spesifikasi voltage $220 \mathrm{~V} \mathrm{50/60} \mathrm{Hz,} 10 \mathrm{~A}$, tekanan maksimal 2,3 $\mathrm{kgf} / \mathrm{cm}^{2}$, kapasitas $0,053 \mathrm{~m}^{3}$; penyimpan data (data logger) merk ELLAB CTF9004 dengan spesifikasi suhu maksimum sampai $350^{\circ} \mathrm{C}$, akurasi $0,1{ }^{\circ} \mathrm{C}$, dan $\mathrm{T}=121,1^{\circ} \mathrm{c}, \mathrm{z}=10^{\circ} \mathrm{C}$; universal testing machine (UTM) merk Zwick model Z005; Alat pengolah data dengan spesifikasi AMD Atthlon TM II X2 260 prosesor 3.20 GHz, RAM 2 GB, 32-bit Operating system; Software yang digunakan untuk melakukan simulasi adalah MATLAB Versi R2010a.

\section{Cara Penelitian}

1. Menyiapkan 12 buah sampel gudeg yang dimasukkan ke dalam kaleng yang telah dipasang 3 buah terminal termokopel (Gambar 2). Urutan komponen penyusun pada kaleng adalah telur, daging ayam, krecek, kacang tolo dan gudeg nangka.

2. Kaleng yang telah terisi bahan dihampakan dengan proses ekshausting kemudian ditutup. 
3. Memasukkan kaleng ke dalam retot dan menyambungkan termokopel pada terminal sesuai urutannya, Retot ditutup dan di-setting pada suhu $111^{\circ} \mathrm{C}$ dan waktu 10 menit (Gambar 3).

4. Menyalakan retot dan data logger. Tunggu sampai operasi sterilisasi selesai.

5. Ulangi prosedur nomor 1 sampai nomor 4 untuk semua variasi perlakuan dengan setting suhu pada retot $\left(111 ; 121\right.$ dan $\left.131^{\circ} \mathrm{C}\right)$ dan setting waktu (10; 20 dan 30 menit).

6. Data kenaikan suhu bahan untuk setiap sampel dengan interval 1 menit akan dicetak pada kertas print out oleh data logger, bersamaan dengan tercetaknya nilai sterilitas sampel (nilai F) pada waktu tertentu.

7. Masing-masing sampel di uji teksturnya dengan menggunakan universal testing machine (UTM) merk Zwick model Z005 untuk mengetahui pengaruh variasi peralakuan.

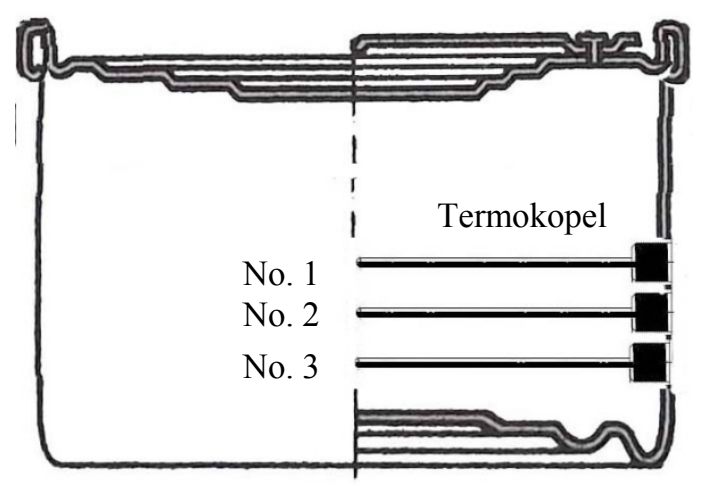

Gambar 2. Arsitektur terminal termokopel pada kaleng

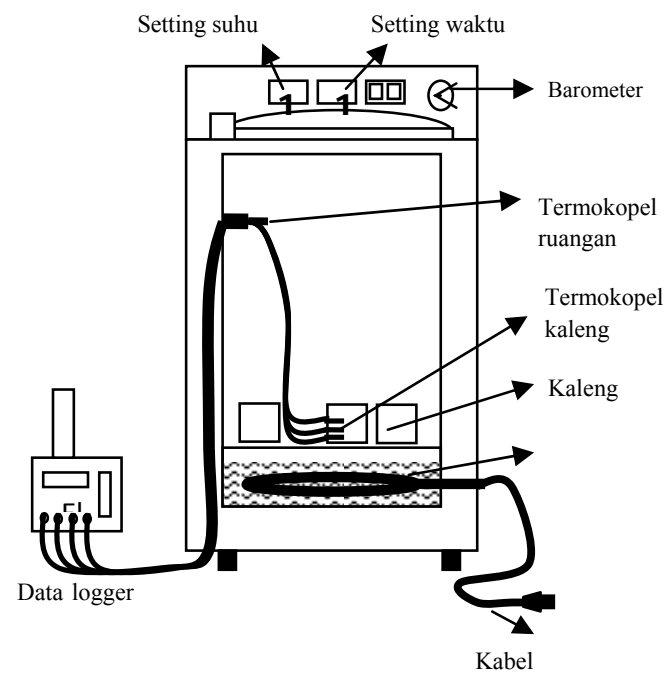

Gambar 3. Skema retot dan penyimpan data.

\section{Analisa data}

Analisa data atau data mining dilakukan terhadap data kenaikan suhu bahan selama proses sterilisasi. Tahapan data mining meliputi eksplorasi data dan validasi model dengan metode prediksi, yaitu memprediksi nilai yang akan datang berdasarkan datadata yang telah ada dengan regresi. Regresi dilakukan untuk mengetahui hubungan kuantitatif antara variabel (Widodo dkk., 2013).

\section{Simulasi Model}

Persamaan diferensial adalah salah satu metode penting dalam pemodelan matematik. Pemecahan persamaan tersebut biasanya dengan menggunakan simulasi komputer dan telah banyak dilakukan oleh para peneliti dalam berbagai kondisi yang berbeda (Weng, 2005; Varma dan Kannan, 2005; Kannan dan Sandaka, 2008; Kiziltas dkk., 2010). Salah satu jenis algoritme yang saat ini banyak dikembangkan adalah soft computing yaitu menghitung dengan bantuan komputasi numerik (Widodo dkk., 2013).

Pertimbangan dasar dalam penggunaan komputasi numerik adalah pemilihan teknik disktritisasi model. Di antara sekian teknik yang paling banyak dipakai adalah teknik beda hingga, salah satu program yang dipakai adalah Matrix Laboratory (MATLAB) (Suarga, 2007). Untuk mendapatkan kestabilan pada model ditetapkan beberapa asumsi berdasarkan beberapa hasil penelitian terdahulu, diantaranya suhu di luar dinding kaleng adalah tetap (Kannan dan Sandaka, 2008), reaksi panas diabaikan (Siriwattanayotin, dkk, 2006), kapasitas panas antara suhu lingkungan dengan dinding kaleng diabaikan sehingga $\mathrm{T}_{\text {dinding }}=\mathrm{T}_{\text {lingkungan }}$ (Kiziltas dkk., 2010). Diagram alir dengan menggunakan MATLAB dapat dilihat pada Gambar 4.

\section{HASIL DAN PEMBAHASAN}

Metode prediksi dengan menerapkan model yang dikembangkan didasarkan pada data-data observasi, hasilnya disajikan pada Gambar 5 sampai Gambar 7.

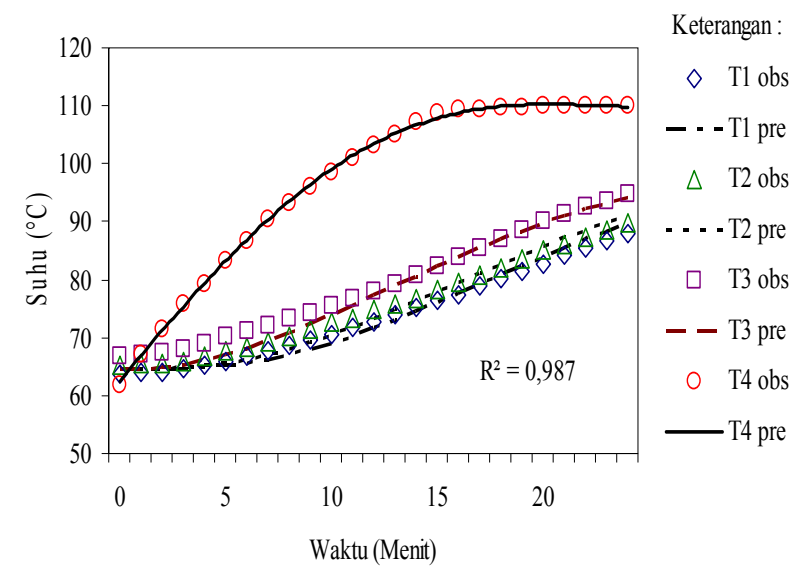

Gambar 5. Fitting data prediksi dan data observasi pada $111^{\circ} \mathrm{C}$ dan 10 menit 


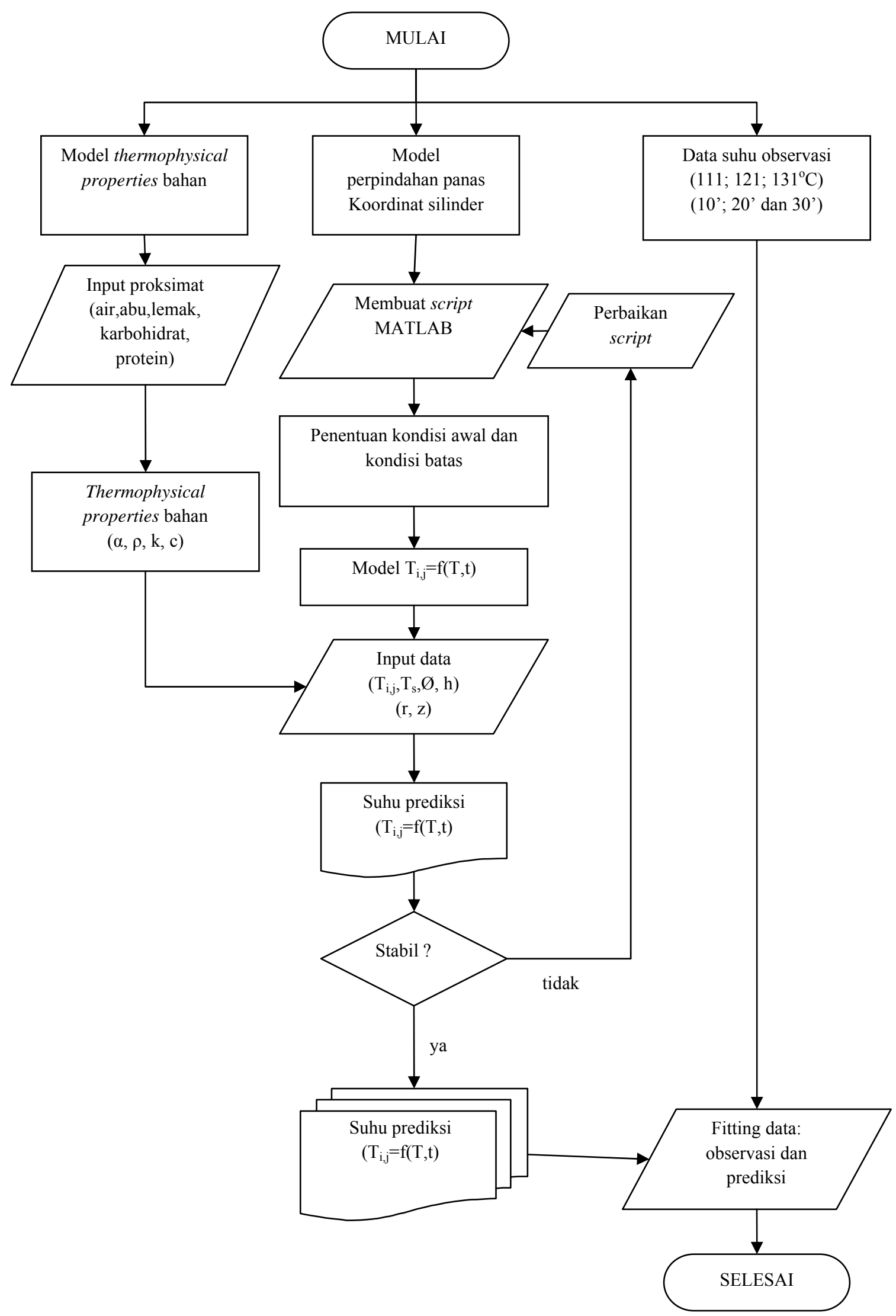

Gambar 4. Diagram alir simulasi dengan MATLAB 


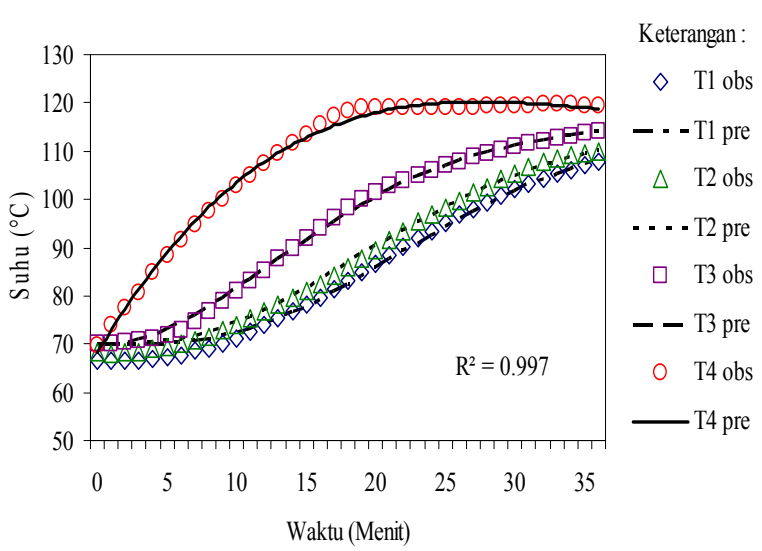

Gambar 6. Fitting data prediksi data dan observasi pada $121^{\circ} \mathrm{C}$ dan 20 menit

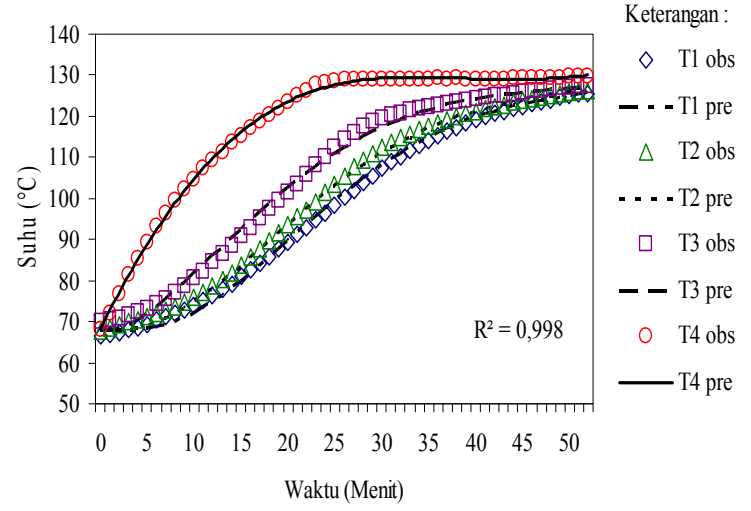

Gambar 7. Fitting data prediksi dan data observasi pada $131^{\circ} \mathrm{C}$ dan 30 menit

Keterangan :

T1 obs : Suhu observasi pada titik 1

T1 pre : Suhu prediksi pada titik 1

T2 obs : : Suhu observasi pada titik 2

T2 pre : Suhu prediksi pada titik 2

T3 obs : : Suhu observasi pada titik 3

T3 pre : Suhu prediksi pada titik 3

T4 obs : : Suhu observasi pada ruangan retot

T4 pre : Suhu prediksi pada ruangan retot

Gambar 5 sampai 7 memperlihatkan hasil fitting data prediksi dengan data observasi. Fitting data menghasilkan antara kedua data tersebut saling berhimpitan dengan koefisien regresi $\left(\mathrm{R}^{2}\right)$ sebesar 0,987 sampai 0,998, artinya model yang dikembangkan cukup valid dan sesuai dengan kasus yang diteliti. Perbedaan nilai antara titik 1, titik 2, dan titik 3 memperlihatkan bahwa pada proses sterilisasi, suhu produk tidak segera mencapai suhu yang dikehendaki, karena panas akan merambat ke dalam kaleng secara perlahan-lahan.

Menurut Kiziltas dkk (2010), jumlah panas yang diperlukan untuk sterilisasi tergantung pada beberapa faktor diantaranya : 1) Ukuran kaleng dan keadaan isinya, kaleng dengan ukuran besar memerlukan waktu lebih lama dari pada kaleng berukuran kecil; 2) Jenis bahan, penetrasi panas pada bahan cair akan lebih cepat dari pada bahan padat; 3) $\mathrm{pH}$ bahan pangan, waktu sterilisasi bahan pangan berasam rendah dapat diperpendek dengan pemanasan pada suhu lebih tinggi; 4) Suhu awal bahan, suhu awal yang cukup $\left(60\right.$ sampai $\left.70^{\circ} \mathrm{C}\right)$ dapat memperpendek waktu sterilisasi; dan 5) Sumber panas, uap air sebagai medium pemanasan harus merupakan uap air murni sehingga proses perpindahan panas berjalan dengan cepat.

Profil suhu hasil simulasi menggunakan MATLAB Versi R2010a disajikan pada Gambar 8 sampai dengan Gambar 10.

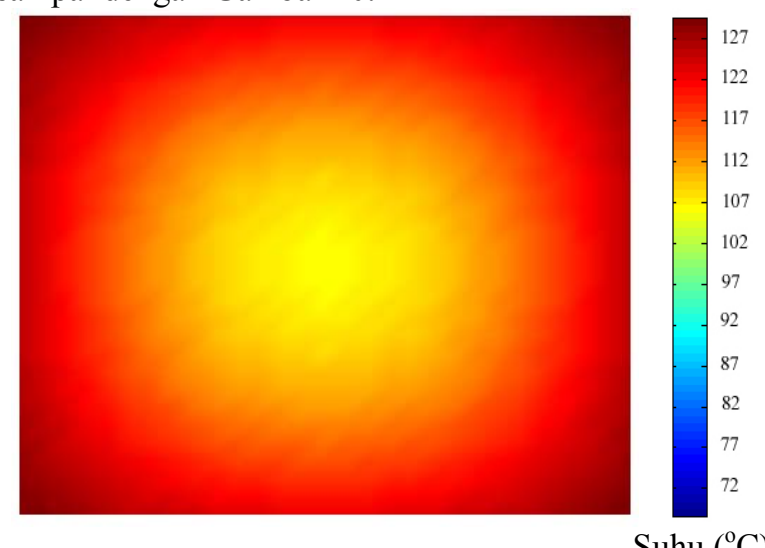

Gambar 8. Hasil simulasi MATLAB pada perlakuan $111^{\circ} \mathrm{C}$ dan 10 menit

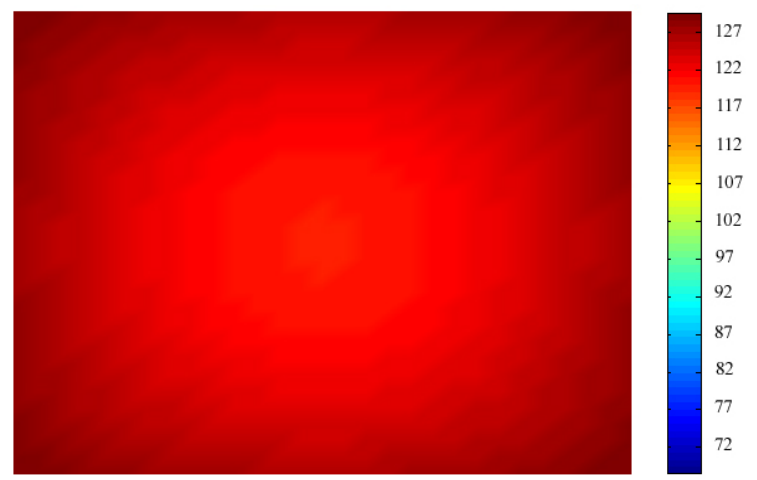

Suhu $\left({ }^{\circ} \mathrm{C}\right)$

Gambar 9. Hasil simulasi MATLAB pada perlakuan $121^{\circ} \mathrm{C}$ dan 20 menit

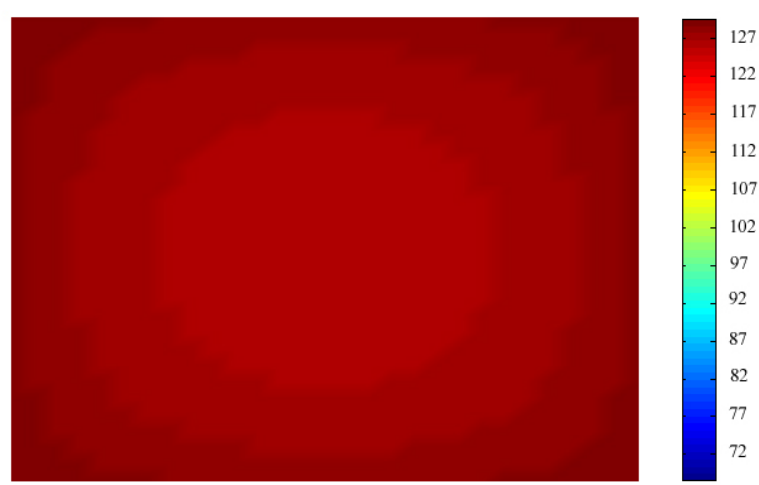

Suhu $\left({ }^{\circ} \mathrm{C}\right)$

Gambar 10. Hasil simulasi MATLAB pada perlakuan $131{ }^{\circ} \mathrm{C}$ dan 30 menit 
Gambar 8 sampai Gambar 10 memperlihatkan profil suhu dalam 2 dimensi untuk setiap variasi peralkuan. Perubahan profil suhu semakin gelap seiring dengan semakin tinggi suhu dan waktu sterilisasi yang dilakukan. Hal ini mengindikasikan bahwa daerah titik terdingin dalam gudeg kaleng mengalami kenaikan suhu sejalan dengan peningkatan suhu dan lama waktu sterilisasi. Pada suhu $111^{\circ} \mathrm{C}$ selama 10 menit bagian tengah kaleng masih terlihat terang, hal ini berarti bahwa pemanasan belum optimal. Pada suhu $121^{\circ} \mathrm{C}$ selama 20 menit bagian tengah telah menunnjukkan warna yang lebih gelap dari sebelumnya. Sementara pada suhu $131^{\circ} \mathrm{C}$ selama 30 menit bagian tengah kaleng terlihat berwarna gelap artinya pemanasan sudah terjadi secara berlebihan.

Untuk mengetahui apakah karakterisasi produk sesuai dengan yang diinginkan. Dilakukan analisis data terhadap nilai sterilitas yang dihasilkan data logger. Istilah sterilisasi mengandung arti suatu perlakuan penghancuran semua mikroba beserta sporanya. Derajat sterilitas yang cukup dapat diperoleh bila titik dingin bahan pangan dalam kaleng cukup menerima panas. Derajat sterilitas biasanya direpresentasikan sebagai nilai $\mathrm{F}$ yaitu waktu dalam menit yang diperlukan untuk menghancurkan mikroba (Goncalves, 2005; Tucker dkk., 2007).

Hasil analisis data terhadap nilai sterilitas disajikan pada Gambar 11.

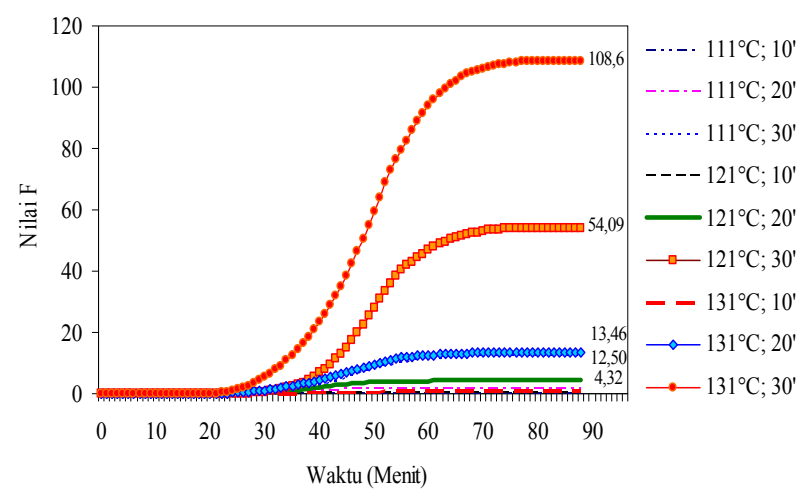

Gambar 11. Nilai sterilitas produk pada beberapa variasi perlakuan

Gambar 11 memperlihatkan nilai sterilitas (F) produk berdasarkan data logger untuk perlakuan $131^{\circ} \mathrm{C}$ pada sterilisasi 30 menit dihasilkan nilai sterilitas sebesar 108,6 menit; pada 20 menit sebesar 54,09 menit dan pada 10 menit sebesar 12,5 menit. Untuk perlakuan $121^{\circ} \mathrm{C}$ pada sterilisasi 30 menit sebesar 13,46 menit; pada 20 menit sebesar 4,32 menit. Sedangkan perlakuan yang lain dihasilkan nilai sterilitas dibawah 4,32 menit. Berdasarkan hasil penelitian yang telah dilakukan sebelumnya untuk membunuh Clostridium botulinum pada makanan kaleng dengan $\mathrm{pH}$ lebih kecil dari 4,5 dimana suhu referensi adalah $121,1^{\circ} \mathrm{C}$ dibutuhkan waktu 3 menit, sementara untuk makanan kaleng dengan $\mathrm{pH}$ lebih besar dari 4,5 waktu yang dibutuhkan adalah 4,2 menit (Fryer dan Robbins, 2005). Sterilisasi standar harus dilakukan pada suhu $121^{\circ} \mathrm{C}$ dengan nilai penghancuran spora $C$. Botulinum sebesar 3 menit hal ini disebut sebagai $\mathrm{F}_{0} 3$ atau botulinum cook (FDA, 2005).

Penggunaan panas pada sterilisasi berpengaruh terhadap mutu bahan makanan seperti tekstur yang akan berubah jika suhu berubah (Lund, 2003). Untuk mengetahui pengaruh perlakuan terhadap nilai tekstur produk dilakukan uji tekstur, hasilnya disajikan pada Gambar 12.

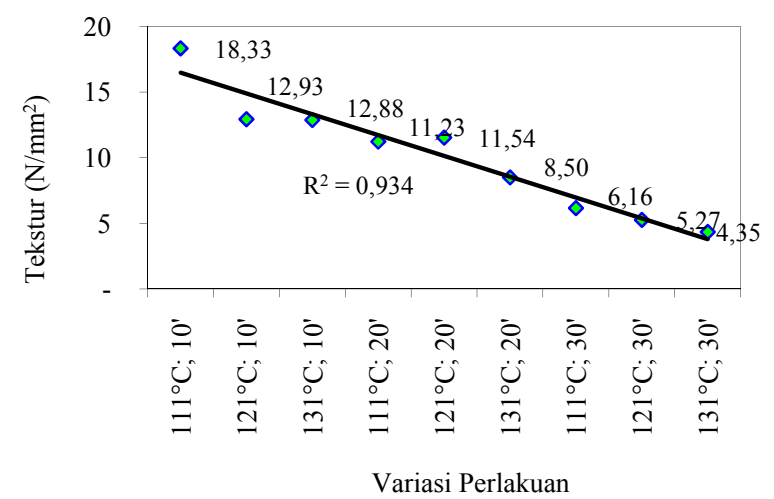

Gambar 12. Hasil uji tekstur sampel pada berbagai perlakuan

Gambar 12 memperlihatkan tekstur gudeg mengalami penurunan sejalan dengan kenaikan suhu dan waktu sterilisasi. Sterilisasi adalah operasi yang paling penting dalam proses pengalengan makanan, tujuannya untuk menghancurkan mikroba pembusuk, membuat produk menjadi masak, tekstur dan cita rasa sesuai dengan yang diinginkan. Oleh karena itu proses pemanasan ini harus dilakukan pada suhu yang cukup tinggi untuk menghancurkan mikroba, tetapi tidak boleh terlalu tinggi sehingga membuat produk menjadi terlalu masak atau tekstur produk yang dihasilkan terlalu lunak (Chinesta, dkk, 2002; Kiziltas, dkk, 2010). Dengan melihat nilai sterilitas 4,3 pada suhu sterilisasi $121^{\circ} \mathrm{C}$ dengan waktu 20 menit didapatkan nilai tekstur sebesar $11,23 \mathrm{~N} / \mathrm{mm}^{2}$.

\section{KESIMPULAN}

Model yang dikembangkan untuk memprediksi kenaikan suhu bahan selama proses sterilisasi ditunjukkan oleh persamaan 11. Fitting data prediksi dan data observasi menghasilkan koefisien regresi antara 0,987 sampai 0,997. Hasil simulasi profil kenaikan suhu bahan dengan MATLAB mengindikasikan bahwa semakin tinggi suhu dan semakin lama proses sterilisasi berlangsung warna produk akan semakin gelap. Variasi perlakuan sangat berpengaruh terhadap nilai sterilitas dan tekstur gudeg kaleng yang dihasilkan. Perlakuan paling optimum didapatkan pada suhu sterilisasi $121^{\circ} \mathrm{C}$ selama 20 menit dengan nilai sterilitas sebesar 4,32 menit dan nilai tekstur sebesar $11,23 \mathrm{~N} / \mathrm{mm}^{2}$. 


$$
\mathrm{T}_{i, j}^{(\mathrm{t}+\Delta \mathrm{t})}=\mathrm{T}_{\mathrm{i}, \mathrm{j}}{ }^{(\mathrm{t})}+\frac{\alpha \Delta \mathrm{t}}{\Delta \mathrm{r}^{2}}\left(\mathrm{~T}_{\mathrm{i}-1, \mathrm{j}}-2 \mathrm{~T}_{\mathrm{i}, \mathrm{j}}+\mathrm{T}_{\mathrm{i}+1, \mathrm{j}}\right)^{(\mathrm{t})}+\frac{\alpha \Delta \mathrm{t}}{2 \mathrm{r} \Delta \mathrm{r}^{2}}\left(\mathrm{~T}_{\mathrm{i}-1, \mathrm{j}}-\mathrm{T}_{\mathrm{i}+1, \mathrm{j}}\right)^{(\mathrm{t})}+\frac{\alpha \Delta \mathrm{t}}{\Delta \mathrm{z}^{2}}\left(\mathrm{~T}_{\mathrm{i}, \mathrm{j}-1}-2 \mathrm{~T}_{\mathrm{i}, \mathrm{j}}+\mathrm{T}_{\mathrm{i}, \mathrm{j}+1}\right)^{(\mathrm{t})}
$$

\section{DAFTAR NOTASI}

\begin{tabular}{|c|c|c|}
\hline $\mathrm{D}$ & $:$ & Diameter kaleng, $\mathrm{m}$ \\
\hline $\mathrm{H}$ & : & Tinggi kaleng, $\mathrm{m}$ \\
\hline $\mathrm{h}$ & : & Setengah tinggi kaleng, $\mathrm{m}$ \\
\hline $\mathrm{k}$ & : & Koefisien konduksi panas, $\mathrm{W} / \mathrm{m}^{\circ} \mathrm{C}$ \\
\hline $\mathrm{n}$ & : & Jumlah data \\
\hline$n_{\mathrm{r}}$ & : & Jumlah diskritisasi arah $\mathrm{r}$ \\
\hline $\mathrm{n}_{\mathrm{z}}$ & : & Jumlah diskritisasi arah z \\
\hline $\mathrm{t}$ & : & Waktu, detik \\
\hline $\mathrm{T}$ & : & Suhu bahan, ${ }^{\circ} \mathrm{C}$ \\
\hline $\mathrm{T}_{\mathrm{L}}$ & : & Suhu lingkungan, ${ }^{\circ} \mathrm{C}$ \\
\hline $\mathrm{T}_{\text {ref }}$ & $:$ & Suhu uap, ${ }^{\circ} \mathrm{C}$ \\
\hline $\mathrm{T}_{\mathrm{i}}$ & : & Suhu di titik i, ${ }^{\circ} \mathrm{C}$ \\
\hline $\mathrm{T}_{\mathrm{j}}$ & $:$ & Suhu di titik $\mathrm{j},{ }^{\circ} \mathrm{C}$ \\
\hline $\mathrm{T}_{\mathrm{i}, \mathrm{j}}$ & $:$ & Suhu di titik i,j, ${ }^{\circ} \mathrm{C}$ \\
\hline $\mathrm{T}_{\mathrm{i}, \mathrm{j}}^{\mathrm{t}}$ & : & Suhu di titik i,j pada waktu $t,{ }^{\circ} \mathrm{C}$ \\
\hline $\mathrm{T}_{\mathrm{i}}^{\mathrm{t}}$ & : & Suhu di titik i pada waktu $t,{ }^{\circ} \mathrm{C}$ \\
\hline $\mathrm{T}_{\mathrm{j}}^{\mathrm{t}}$ & $:$ & Suhu di titik j pada waktu $t,{ }^{\circ} \mathrm{C}$ \\
\hline$T_{i, j}^{t+\Delta t}$ & $:$ & Suhu di titik i,j pada waktu $\mathrm{t}+\Delta \mathrm{t},{ }^{\circ} \mathrm{C}$ \\
\hline $\mathrm{T}_{\mathrm{j}}^{\mathrm{t}+\Delta \mathrm{t}}$ & : & Suhu di titik j pada waktu $\mathrm{t}+\Delta \mathrm{t},{ }^{\circ} \mathrm{C}$ \\
\hline $\mathrm{T}_{\mathrm{i}}^{\mathrm{t}+\Delta \mathrm{t}}$ & : & Suhu di titik i pada waktu $\mathrm{t}+\Delta \mathrm{t},{ }^{\circ} \mathrm{C}$ \\
\hline $\mathrm{r}$ & & arah radial \\
\hline $\mathrm{z}$ & • & arah aksial \\
\hline$\alpha$ & : & Difusivitas bahan, $\mathrm{m}^{2} / \mathrm{s}$ \\
\hline$\rho$ & : & Berat jenis bahan, $\mathrm{kg} / \mathrm{m}^{3}$ \\
\hline c & : & Panas jenis bahan \\
\hline$\Delta \mathrm{r}$ & : & jarak inkremen arah radial \\
\hline$\Delta \mathrm{z}$ & & jarak inkremen arah aksial \\
\hline$\Delta \mathrm{t}$ & ( & perubahan waktu, detik \\
\hline
\end{tabular}

\section{UCAPAN TERIMAKASIH}

Terima kasih diucapkan kepada Kementerian Riset dan Teknologi Republik Indonesia atas sponsorship terhadap penulis untuk melanjutkan studi, Gudeg Kaleng Bu Tjitro 1925, Tim Pengalengan UPT BPPTK LIPI dan Tim Asisten Laboratorium Komputer, Jurusan Teknik Kimia, Fakultas Teknik UGM.

\section{DAFTAR PUSTAKA}

Awuah, G.B., Ramaswamy, H.S., and Economides, A., (2007), Thermal Processing and Quality: Principles and Overview, Chemical Engineering and Processing, 46, pp. 584-602.

Chinesta, F., Torres, R., Ramon, A., Rodrigo, M.C., And Rodrigo, M., (2002), Homogenized Thermal Condustion Model for Particulate Foods, Journal Food Engineering, 80, pp. 80-95.
Dewitt, D.P. and Incropera, F.P., (2001), Fundamentals of Heat and mass Tansfer, $5^{\text {th }}$, John Wiley, New York.

Food and Drug Administration (FDA), (2005), Food and Drugs, Chapter 1-Food and Drug Administration Departement of Health and Human Services, Subchapter B-Food for Human Consumption, Code of federal Regulations, Title 21, Volume Revised as of April 1, 2005.

Fryer, J.F. and Robbins, P.T., (2005), Heat transfer in Food Processing: Ensuring Product Quality and Safety, Applied Thermal Engineering, 25, pp. 24992510 .

Goncalves, E.C., Minim, L.A. Coimbra, J.S.R., and Minim, V.P.R., (2005), Modelling Sterilization Process of Canned Foods using Artificial Neural Networks, Chemical Engineering and Processing, 44, pp. 1269-1276.

Gorunescu, F., (2011), Data Mining-Concepts, Models, and Techniques, Berlin: Springer-Verlag Berlin Heidelberg.

Ibarz, A. and Canovas, G.V.B., (2003), Unit Operation in Food Engineering, CRC Press, Florida.

Kannan, A. and Sandaka P.Ch.G., (2008), Heat Transfer Analisys of Canned Food Sterilization in Still Retot, Journal of Food Engineering, 88, pp. 213-228.

Kiziltas, S., Erdogdu, F., and Palazoglu, T.K., (2010), Simulation of Heat Transfer for Solid-liquid Food Mixture in Cans and Model Validation under Pasteurization Conditions, Journal Food Engineering, 97, pp. 449-456.

Larousse, J. and Brown, B.E., (1997), Food Canning Technology, Wiley VCH, New York.

Lund, D., (2003), Predicting the Impact of Food Processing on Food Constituents, Journal of Food Engineering, 56, pp. 113-117.

Marra, F. and Romano, V., (2003), A Mathematical Model to Study the Influence of Wireless Temperature sensor during Assesment of Canned Food Sterilization, Journal of Food Engineering, 59, pp. 245-252.

Siriwattayotin, S., Yoovidha, T., Meepadung, T., and Ruenglertpanyakul, W., (2006), Simulation of Sterilization of Canned Liquid Food using Sucrose degradation as an indicator, Journal of Food Engineering, 73, pp. 307-312.

Stoforos, N.G., (1995), Thermal Process Design, Food Control, Vol 6, No. 2, pp. 81-95. 
Suarga, (2007), Fisika Komputasi; Solusi Problema Fisika dengan MATLAB, Penerbit Andi, Yogyakarta

Tucker, G.S., Brown, H.M., Fryer, P.J., Cox, P.W., Poole II, F.L., Lee, H.S., and Adams, M.W.W., (2007), A Sterilization Time-Temperatur Integrator based on Amylase from the hyperthermophilic organism Pyrococcus furius, Inovatitive Food Science and Emerging Technologies, pp. 63-72.

Weng, Z.J., (2005), Thermal Processing of Canned Foods. In: Sun, Da-Wen (Ed). Thermal Food
Processing; New Technology and Quality Issue. CRC Talyor and Francis. Boca Raton. Florida (Chapter 11).

Widodo, P.P., Handayanto, R.T., dan Herlawati, (2013), Penerapan Data Mining dengan MATLAB, Penerbit Rekayasa Sains, Bandung.

Varma, M. and Kannan, N., (2005), Enhance Food Sterilization Through Inclination Of The Container Walls And Geometry Modifications, International Journal of Heat and Mass Transfer, 48 (18), pp. 3753 3762 . 